\title{
Molecular and Functional Evidence for In Vitro Cytokine Enhancement of Human and Murine Target Cell Sensitivity to Glucocorticoids \\ TNF- $\alpha$ Priming Increases Glucocorticoid Inhibition of TNF- $\alpha$-induced Cytotoxicity/Apoptosis
}

\author{
Mónica Costas, ${ }^{\star}$ Thorsten Trapp, ${ }^{\S}$ Marcelo Páez Pereda, ${ }^{\star}$ Joachim Sauer, ${ }^{\S}$ Rainer Rupprecht, ${ }^{\S}$ Víctor E. Nahmod, \\ Johannes M.H.M. Reul, ${ }^{\S}$ Florian Holsboer, ${ }^{\S}$ and Eduardo Arzt ${ }^{\star \ddagger}$ \\ *Instituto de Investigaciones Médicas, Universidad de Buenos Aires, 1427 Buenos Aires, Argentina; ${ }^{\ddagger}$ Departamento de Biología-FCEN, \\ Universidad de Buenos Aires and Argentine National Research Council (CONICET), 1427 Buenos Aires, Argentina; and \\ ${ }^{\S}$ Max-Planck-Institute of Psychiatry, Clinical Institute, 80804 Munich, Germany
}

\begin{abstract}
Cytokine-induced glucocorticoid secretion and glucocorticoid inhibition of cytokine synthesis and pleiotropic actions act as important safeguards in preventing cytokine overreaction. We found that TNF- $\alpha$ increased glucocorticoid-induced transcriptional activity of the glucocorticoid receptor (GR) via the glucocorticoid response elements (GRE) in L-929 mouse fibroblasts transfected with a glucocorticoid-inducible reporter plasmid. In addition, $\mathrm{TNF}-\alpha$ also enhanced GR number. The TNF- $\alpha$ effect on transcriptional activity was absent in other cell lines that express TNF- $\alpha$ receptors but not GRs, and became manifest when a GR expression vector was cotransfected, indicating that TNF- $\alpha$, independent of any effect it may have on GR number, has a stimulatory effect on the glucocorticoid-induced transcriptional activity of the GR. Moreover, TNF- $\alpha$ increased GR binding to GRE. As a functional biological correlate of this mechanism, priming of L-929 cells with a low (noncytotoxic) dose of TNF- $\alpha$ significantly increased the sensitivity to glucocorticoid inhibition of TNF- $\alpha$-induced cytotoxicity/apoptosis. TNF- $\alpha$ and IL-1 $\beta$ had the same stimulatory action on glucocorticoid-induced transcriptional activity of the GR via the GRE, in different types of cytokine/glucocorticoid target cells (glioma, pituitary, epithelioid). The phenomenon may therefore reflect a general molecular mechanism whereby cytokines modulate the transcriptional activity of the GR, thus potentiating the counterregulation by glucocorticoids at the level of their target cells. (J. Clin. Invest. 1996. 98: 1409-1416.) Key words: cytokines $\bullet$ TNF- $\alpha \cdot$ glucocorticoid receptor • glucocorticoid response element • apoptosis
\end{abstract}

\section{Introduction}

An important feature of immune or inflammatory responses is the marked increase in cytokine synthesis. These cytokines ac-

\footnotetext{
Address correspondence to Dr. Eduardo Arzt, Instituto de Investigaciones Médicas, Donato Alvarez 3150, 1427 Buenos Aires, Argentina. Phone: 54-1-5220061/64; FAX: 54-1-8225925; E-mail: postmaster@arzt.ba.ar

Received for publication 13 December 1995 and accepted in revised form 15 July 1996.
}

J. Clin. Invest.

(C) The American Society for Clinical Investigation, Inc.

0021-9738/96/09/1409/08 \$2.00

Volume 98, Number 6, September 1996, 1409-1416 tivate the hypothalamic-pituitary-adrenal system, causing an elevation of systemic glucocorticoid levels $(1,2)$. Glucocorticoids inhibit both cytokine gene expression and pleiotropic actions on target cells, acting as immunosuppressive and antiinflammatory agents that contain overreactions of the immune system, as well as autoaggressive responses (3-7).

There is evidence that endotoxin and/or inflammatory cytokines increase the number of glucocorticoid receptors $(\mathrm{GR})^{1}$ in murine macrophages (8) and human lymphoid, monocytoid, and hepatoma cell lines (9). However, sensitivity to glucocorticoids may involve other mechanisms, since tissues with similar GR capacity show widely varying responsiveness to glucocorticoids $(10,11)$. Noncytokine immune factors, such as immunophilins $(12,13)$, have been shown to regulate glucocorticoidinduced GR-mediated gene transcription. Immune mediators may exert their regulatory effects through a cross talk at the level of specific nucleotide sequences present in genes whose transcription is modulated by glucocorticoids. Were this the case, then cytokines, in addition to inducing glucocorticoid secretion $(1,2)$, might modulate the action of glucocorticoids at the target cell level, increasing the cell's sensitivity to the inhibitory effect of glucocorticoids after infection or inflammation.

To examine this possibility, we studied the effects of cytokines on the capacity and transcriptional activity of GR via the glucocorticoid response elements (GRE) in different target cell lines. In addition, we examined the consequences on the biological action of glucocorticoids on these cells.

\section{Methods}

Cells and reagents. The cell lines L-929 (mouse fibroblasts), AtT-20 (mouse anterior pituitary cells), U-373 (human glioblastoma), HeLa (human epithelioid carcinoma cells), CV1 (monkey kidney cells), and SK-N-MC (human neuroblastoma) were grown in DME (Gibco Laboratories, Grand Island, NY) supplemented with $10 \%$ charcoalstripped steroid-free FCS (Gibco, Paisley, United Kingdom), penicillin $(100 \mathrm{U} / \mathrm{ml})$, and streptomycin $(100 \mu \mathrm{g} / \mathrm{ml})$. The cells were maintained at $37^{\circ} \mathrm{C}$ in a humidified atmosphere of $5 \% \mathrm{CO}_{2}$. Unless stated, reagents were from Sigma Chemical Co. (St. Louis, MO), Boehringer (Mannheim, Germany), or Pharmacia (Uppsala, Sweden).

Construction of reporter and expression plasmids. The construction of the reporter plasmids MTV-CAT, MTV-LUC, and $\triangle \mathrm{MTV}$ -

1. Abbreviations used in this paper: CAT, chloramphenicol acetyltransferase; DEX, dexamethasone; EMSA, electrophoretic mobility shift assay; GR, glucocorticoid receptor; GRE, glucocorticoid responding element; LTR, long terminal repeat; LUC, luciferase; MTV, mammary tumor virus. 
CAT have been described previously (14). Briefly, the MTV-CAT is a glucocorticoid-inducible reporter plasmid containing the complete mouse mammary tumor virus-long terminal repeat (MTV-LTR) promoter upstream of the gene for chloramphenicol acetyltransferase (CAT), while the MTV-LUC contains luciferase (LUC) as reporter gene. The $\triangle$ MTV-CAT plasmid contains a modified MTV-LTR sequence upstream of the CAT reporter gene in which bases -190 to -88 have been deleted, thus eliminating three out of the four consensus GRE known to reside within the MTV-LTR (15).

The plasmid pRShGR $\alpha$, described previously (16), is an expression vector for the GR under the control of the RSV promoter.

The plasmid pCH110 (Pharmacia, Freiburg, Germany) contains a functional lac $\mathrm{Z}$ gene, coding for $\beta$-galactosidase, under the transcriptional control of the SV40 early promoter.

Transfections and assays of CAT, LUC, and $\beta$-galactosidase activities. L-929, U-373, HeLa, and AtT-20 cell lines were transfected by calcium phosphate coprecipitation, according to the described method (17). Briefly, cells were cultured in plates of $10 \mathrm{~cm}$ at $80 \%$ of confluence in DME with $10 \%$ charcoal-stripped steroid-free FCS. Medium was removed and $1 \mathrm{ml}$ of the transfection buffer (Hepes$\mathrm{CaCl}_{2}$ ) containing $20 \mu \mathrm{g}$ of MTV-CAT plasmid was added. After 20 min, $9 \mathrm{ml}$ of culture medium was added and plates were incubated at $37^{\circ} \mathrm{C}$ and $5 \%$ of $\mathrm{CO}_{2}$ for $4 \mathrm{~h}$. Cells were then shocked with Hepesglycerol $15 \%, 3$ min, washed twice with PBS, and incubated with DME with $10 \%$ charcoal-stripped FCS in the presence of TNF- $\alpha$ (R \& D Systems, Minneapolis, MN), IL-1 $\beta$, or dexamethasone (DEX) during $24 \mathrm{~h}$. Cellular extracts for CAT assay were made by freezethaw lysis and CAT assay was performed as described (18). CV1 and SK-N-MC cell lines were transfected by the electroporation method as described $(19,20)$. Briefly, cells were seeded at high density $5 \times 10^{4} /$ $\mathrm{cm}^{2}$ in DME with $10 \%$ charcoal-stripped steroid-free FCS. Cells were then allowed to grow to $75 \%$ confluence. Transfection was carried out using an electroporation system (Biotechnologies and Experimental Research Inc., San Diego, CA). $5 \mu \mathrm{g}$ of the reporter plasmid MTV-LUC and in some cases $5 \mu \mathrm{g}$ of the GR expression vector $\mathrm{pRShGR} \alpha$ were cotransfected. Electroporated cells were replated in DME supplemented with $10 \%$ steroid-free FCS and incubated immediately with glucocorticoids and TNF- $\alpha$. After $24 \mathrm{~h}$, cells were harvested and extracts were assayed for LUC activity (21).

For all cells, $5 \mu \mathrm{g}$ of pCH110 was cotransfected and $\beta$-galactosidase activity was measured (22) in order to correct for variations in transfection efficiency.

Determination of $555 T N F-\alpha$ receptor $m R N A$. Northern blot was performed as described previously (23). Briefly, total RNA, isolated by the guanidine isothiocyanate phenol-chloroform extraction method, was denatured with glyoxal, electrophoresed on a $1.2 \%$ agarose gel, and transferred overnight to a nylon membrane. Filters were baked for $2 \mathrm{~h}$ at $80^{\circ} \mathrm{C}$ and stained with methylene blue. They were prehybridized for $4 \mathrm{~h}$ at $60^{\circ} \mathrm{C}(50 \%$ formamide, $5 \times$ SSPE, $5 \times$ Denhardt's solution, $0.1 \%$ SDS, $100 \mu \mathrm{g} / \mathrm{ml}$ denatured salmon sperm DNA) and then the probe was added for $12 \mathrm{~h}$. Blots were washed at increasing salt and temperature stringency with a final wash of $30 \mathrm{~min}$ at $60^{\circ} \mathrm{C}$ in $0.1 \times$ SSC containing $0.1 \%$ SDS. Dried filters were exposed to Kodak XAR5 film at $-70^{\circ} \mathrm{C}$ with intensifying screens for $2 \mathrm{~d}$. The p55 TNF- $\alpha$ receptor (PstI-BamHI $0.738 \mathrm{~kb}$ ) and $1 \mathrm{~kb}$ PstI actin cDNA probes (specific activity, $2-4 \times 10^{8} \mathrm{cpm} / \mu \mathrm{g}$ ) were labeled with a randompriming kit using $\left[\alpha{ }^{32} \mathrm{P}\right] \mathrm{dCTP}$. The blots were reprobed after eluting the first probe with $5 \mathrm{mM}$ Tris/ $\mathrm{HCl}, \mathrm{pH}$ 8.0, $2 \mathrm{mM}$ EDTA, $0.1 \times$ Denhardt's solution, at $65^{\circ} \mathrm{C}$ for $2 \mathrm{~h}$. A control with the $\alpha{ }^{-32} \mathrm{P}-$ labeled $1-\mathrm{kb}$ PstI fragment of actin cDNA as probe was performed in each blot.

Electrophoretic mobility shift assay (EMSA). EMSA was performed as described previously (19). Briefly, after 15, 45, 60, or 120 min of stimulation, L-929 cells were collected, washed with PBS, and nuclear protein extracted as follows. Cells were lysed in $100 \mu \mathrm{l}$ of buffer A (10 mM Hepes, $1.5 \mathrm{mM} \mathrm{MgCl}_{2}, 10 \mathrm{mM} \mathrm{KCl}, 0.5 \mathrm{mM}$ DTT, and $0.1 \% \mathrm{NP}-40)$. After centrifugation, the nuclear pellet was lysed with $20 \mu \mathrm{l}$ of buffer B ( $20 \mathrm{mM}$ Hepes, $1.5 \mathrm{mM} \mathrm{MgCl}_{2}, 0.42 \mathrm{mM} \mathrm{NaCl}$, $0.5 \mathrm{mM}$ DTT, $0.5 \mathrm{mM}$ PMSF, $25 \%$ glycerol, and $0.2 \mathrm{mM}$ EDTA). The subsequent soluble fraction was mixed with $100 \mu \mathrm{l}$ of buffer $\mathrm{C}(10$ $\mathrm{mM}$ Tris- $\mathrm{HCl}, \mathrm{pH} 7.5,80 \mathrm{mM} \mathrm{KCl}, 10 \%$ glycerol, and $1 \mathrm{mM}$ DTT). Double-stranded oligonucleotides encoding the GRE (5'AGCTTCGTAGCTAGAACATCATGTTCTGG-3') (19) and the NFkB binding site ( $5^{\prime}$ TCGAAATGTGGGATTTTCCCATGAGT-3') were end-labeled incorporating $\left[\alpha{ }^{32} \mathrm{P}\right] \mathrm{CTP}$ and filling in the recessed ends using Klenow fragment (Boehringer). The unrelated double-stranded oligonucleotide CCAAT (5'GATCCCGGAGCCCGGGCCAATCGGCGCA- $\left.3^{\prime}\right)$ was end-labeled using $\left[\gamma^{-32} \mathrm{P}\right] \mathrm{ATP}$ and $\mathrm{T}_{4}$ polynucleotide kinase. Equal amounts $(10-16 \mu \mathrm{g})$ of each sample or RelA (a generous gift from Dr. H. Martinetto, INGEBI, Argentina) were incubated in a total volume of $20 \mu \mathrm{l}$ of buffer containing $600 \mathrm{ng}$ or $1 \mu \mathrm{g}$ of poly $(\mathrm{dI}-\mathrm{dC}) \cdot(\mathrm{dI}-\mathrm{dC})$. A 50-100-fold excess of unlabeled GRE, NFkB binding site, or nonspecific competitor oligomer CCAAT was included in the reaction where indicated. After incubation on ice for 10 min, end-labeled oligonucleotides $(17,000 \mathrm{cpm})$ were added and the incubation was continued for $20 \mathrm{~min}$ at $25^{\circ} \mathrm{C}$. DNA-protein complexes were resolved on a $4 \%$ nondenaturing polyacrylamide gel with buffer recirculation in $6.7 \mathrm{mM}$ Tris- $\mathrm{HCl}(\mathrm{pH} 7.5), 3.3 \mathrm{mM}$ sodium acetate, $1 \mathrm{mM}$ EDTA. The gels were dried under vacuum and autoradiographed at $-70^{\circ} \mathrm{C}$.

Cytotoxicity assay. Cytotoxicity was performed as described (24). Briefly, L-929 cells were plated at $3 \times 10^{5}$ cells/well in 96-well microtiter plates in the presence of different doses of TNF- $\alpha$ and DEX for $24 \mathrm{~h}$. For the priming experiments, TNF- $\alpha 0.02 \mathrm{ng} / \mathrm{ml}$ was added before for $12 \mathrm{~h}$. Plates were stained with $0.5 \%$ gentian violet in $70 \%$ methanol and were then washed and resuspended in acetic $33 \%$ solution; the absorbance was determined at $570 \mathrm{~nm}$.

Apoptosis. L-929 cells were seeded in chamber slides at a density of $4 \times 10^{5}$ cells $/ \mathrm{ml}$, with TNF- $\alpha 60 \mathrm{ng} / \mathrm{ml}$ and DEX 10 or $100 \mathrm{nM}$ for $8 \mathrm{~h}$, and apoptosis was determined by the terminal transferase-mediated dUTP-biotin nick end labeling method (TUNEL) (25). Briefly, after incubation, cells were washed three times with ice-cold PBS and fixed with $2 \%$ paraformaldehyde in PBS (30 min, room temperature). They were then washed once, permeabilized by incubating ( $2 \mathrm{~min}$, $4^{\circ} \mathrm{C}$ ) with $0.1 \%$ Triton $/ 0.1 \%$ sodium citrate and then washed twice with PBS. The TUNEL reaction was carried out by incubating the cells in a moist chamber $\left(1 \mathrm{~h}, 37^{\circ} \mathrm{C}\right)$ with $0.5 \mathrm{nmol}$ biotin-16-dUTP, $3 \mathrm{nmol}$ dATP, $2 \mu \mathrm{l} 25 \mathrm{mM} \mathrm{CoCl}_{2}, 25 \mathrm{U}$ terminal transferase (TdT) (Boehringer) and TdT buffer ( $25 \mathrm{mM}$ Tris- $\mathrm{HCl}, \mathrm{pH} 7.2,200 \mathrm{mM}$ potassium cacodylate) in a total reaction volume of $50 \mu \mathrm{l}$ for each condition. The reaction was stopped by adding $2 \mu \mathrm{l} 0.5 \mathrm{M}$ EDTA. Cells were washed and incubated with a 1:500 dilution of rhodamine-conjugated streptavidin (Dianova, Hamburg, Germany) for $45 \mathrm{~min}$. After washing three times, cells were analyzed for fluorescence in an Olympus IMT-2 microscope. DNase treatment was used as positive control. The number of apoptotic cells was determined by counting at least 10 different fields for each sample.

GR measurement. L-929 cells were processed as described previously (26). The cells were collected by centrifugation and the pellet was homogenized (two pellets, $2 \times 10^{7}$ cells $/ 2 \mathrm{ml}$; 10 strokes at 900 $\mathrm{rpm}$ ) in ice-cold $5 \mathrm{mM}$ Tris- $\mathrm{HCl}(\mathrm{pH} 7.4)$ containing $0.5 \mathrm{mM}$ phenylmethylsulfonyl fluoride, $5 \mu \mathrm{g} / \mathrm{ml}$ antipain, $5 \mu \mathrm{g} / \mathrm{ml}$ leupeptin, $5 \%$ glycerol, $10 \mathrm{mM}$ sodium molybdate, $1 \mathrm{mM}$ EDTA, and $2 \mathrm{mM} \beta$-mercaptoethanol. The homogenate was centrifuged at $100,000 \mathrm{~g}$ for $60 \mathrm{~min}$ at $0-2^{\circ} \mathrm{C}$ to obtain cytosol (i.e., supernatant fraction). Aliquots of cytosol $(100 \mu \mathrm{l})$ were incubated with ${ }^{3} \mathrm{H}$-labeled steroids over a concentration range of $0.5-10 \mathrm{nM}$ (seven concentrations; total volume 150 $\mu \mathrm{l})$. Total binding to soluble macromolecules was determined with ${ }^{3} \mathrm{H}$-DEX (85-106 Ci/mmol; Amersham, Braunschweig, Germany). Nonspecific binding was determined in parallel incubations containing a 1,000-fold excess of DEX in addition to cytosol and ${ }^{3} \mathrm{H}-\mathrm{DEX}$. After incubation for $20-24 \mathrm{~h}$ at $0{ }^{\circ} \mathrm{C}$, bound and free ${ }^{3} \mathrm{H}$-DEX were separated by Sephadex LH-20 (Pharmacia, Sweden) gel filtration and radioactivity was measured in a liquid scintillation counter. The protein concentration was determined by the method of Lowry (27) with BSA as the standard. Nonspecific binding was subtracted from total binding to yield specific binding. Binding data were expressed as fem- 
tomoles per milligram of protein $(\mathrm{fmol} / \mathrm{mg}$ ) and the maximal number of binding sites $\left(\mathrm{B}_{\max }\right)$ and relative binding affinity $\left(K_{\mathrm{d}}\right)$ were determined by nonlinear regression analysis.

Statistics. Statistics were performed using one-way ANOVA in combination with Scheffé's test. Results are expressed as mean \pm SEM.

\section{Results}

TNF- $\alpha$ increases GR number and glucocorticoid-induced transcriptional activity. In mouse L-929 fibroblasts (TNF- $\alpha$ target cells that express GRs) transiently transfected with the plasmid MTV-CAT, noncytotoxic doses of TNF- $\alpha$ increased glucocorticoid-induced CAT activity (Fig. 1). This enhancement was blocked by addition of RU 38486, which antagonizes the GR (Fig. 1), and was absent in cells transfected with a vector
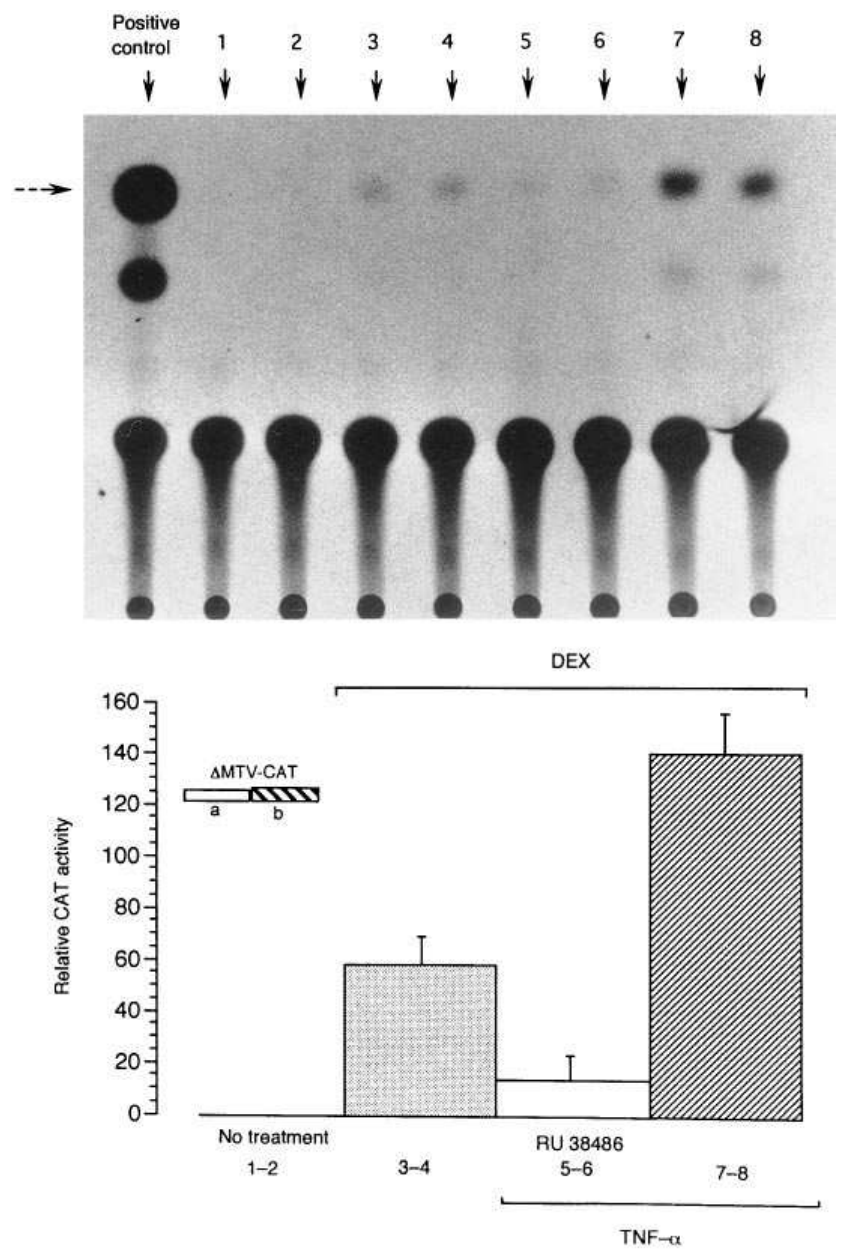

Figure 1. TNF- $\alpha$ enhancement of glucocorticoid-induced transcriptional activity of GR via GRE in MTV-CAT transfected L-929 cells. Cells were transfected and stimulated with DEX $(10 \mathrm{nM}), \mathrm{TNF}-\alpha$ $(0.02 \mathrm{ng} / \mathrm{ml})$, or the glucocorticoid antagonist RU $38486(1 \mu \mathrm{M})$ for $24 \mathrm{~h}$. The diagram bar corresponds to the mean \pm SEM of the densitometric analysis of CAT assay, standardized by the corresponding $\beta$-galactosidase, of six independent experiments. In each of them, duplicates of CAT assay (broken arrow indicates 3-acetylchloramphenicol position) were performed. Similar patterns were obtained using cortisol (concentration range either $3-10 \mu \mathrm{M}$ or 3-10 nM) instead of DEX or a dose of $0.04 \mathrm{ng} / \mathrm{ml} \mathrm{TNF- \alpha .} \mathrm{(Inset)} \mathrm{Transfection} \mathrm{with}$ $\triangle$ MTV-CAT: $a$, no treatment; $b$, stimulation with either DEX or $\mathrm{DEX}+\mathrm{TNF}-\alpha$ for $24 \mathrm{~h}$. lacking GREs (Fig. 1, inset), indicating that the effect on CAT activity is exerted via the GREs. TNF- $\alpha$ itself had no effect on CAT activity (not shown).

TNF- $\alpha$ also led to an increase in GR number in L-929 cells but did not alter receptor affinity (Fig. 2).

Transfection with the MTV-LUC plasmid in two cell lines that express TNF- $\alpha$ receptors (Fig. 3 A, inset) but not GRs (CV1 monkey kidney cells and SK-N-MC human neuroblastoma) did not lead to any reporter gene activity in response to either glucocorticoid on its own or combined with TNF- $\alpha$ (Fig. 3 A). However, TNF- $\alpha$ enhancement of glucocorticoid-induced transcriptional activity was present when both cell lines were cotransfected with MTV-LUC and an expression vector for the GR under the RSV promoter (Fig. 3 B). TNF- $\alpha$ did not alter LUC expression of the construct RSV-LUC, which contains the promoter (RSV) from the GR expression vector (not shown). This indicates that $\mathrm{TNF}_{-} \alpha$, independent of any effect it may have on GR number, has a stimulatory effect on the glucocorticoid-induced transcriptional activity of the GR via the GRE. This action is more pronounced in target cells that express these receptors naturally, because TNF- $\alpha$ also leads to an increase in GR number.

TNF- $\alpha$ increased the DEX-induced binding of the GR to the GRE, as shown by EMSA, even at time points (e.g., 15 min) at which an effect of an increase in GR number is most probably negligible (28) (Fig. $4 A$, lanes 4 and 5 and Fig. $4 B$, lanes 1 and 2). The specificity for GRE binding of the electrophoretic mobility shift complexes obtained with DEX and $\mathrm{TNF}-\alpha$ was demonstrated using unlabeled oligomers in competition experiments. A 50-100-fold excess of unlabeled GRE competed efficiently for receptor binding (Fig. $4 A$, lanes 3 and 6 and Fig. $4 B$, lane 4 ) in contrast to the same excess of an unrelated oligomer (Fig. $4 A$, lanes 1 and 2 and Fig. $4 B$, lane 3 ). When an oligonucleotide encoding the CCAAT site of the fibronectin gene was used as control probe, no differences in the

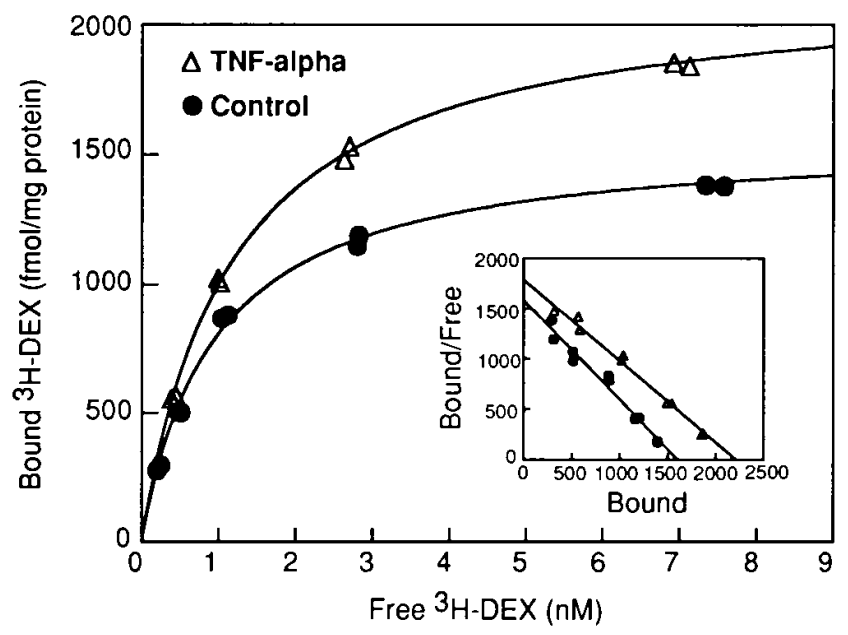

Figure 2. TNF- $\alpha$ enhancement of GR number in L-929 cells. Saturation binding and Scatchard analysis (inset) of GR in L-929 cells after $12 \mathrm{~h}$ of stimulation with $0.02 \mathrm{ng} / \mathrm{ml}$ of TNF- $\alpha$. Similar results were obtained in two independent experiments ( $n=3$ for each condition). Stimulation with TNF- $\alpha$ produced a profound increase in GR concentration $\left(\mathrm{B}_{\max }: 2,173 \mathrm{fmol} / \mathrm{mg}[\mathrm{TNF}-\alpha]\right.$ vs. $1,611 \mathrm{fmol} / \mathrm{mg}$ [untreated] $)(P<0.01)$, whereas no change was observed in the apparent binding affinity $\left(K_{\mathrm{d}}: 1.2 \mathrm{nM}[\mathrm{TNF}-\alpha]\right.$ vs. $1.0 \mathrm{nM}$ [untreated]). 


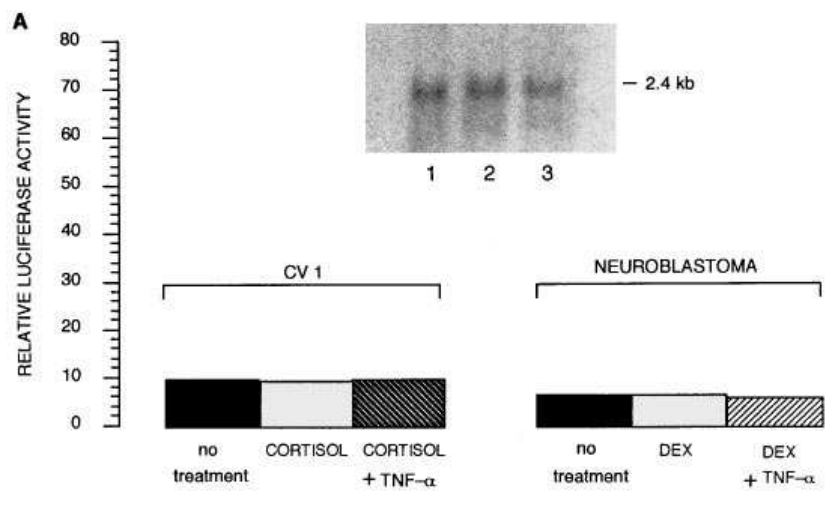

B

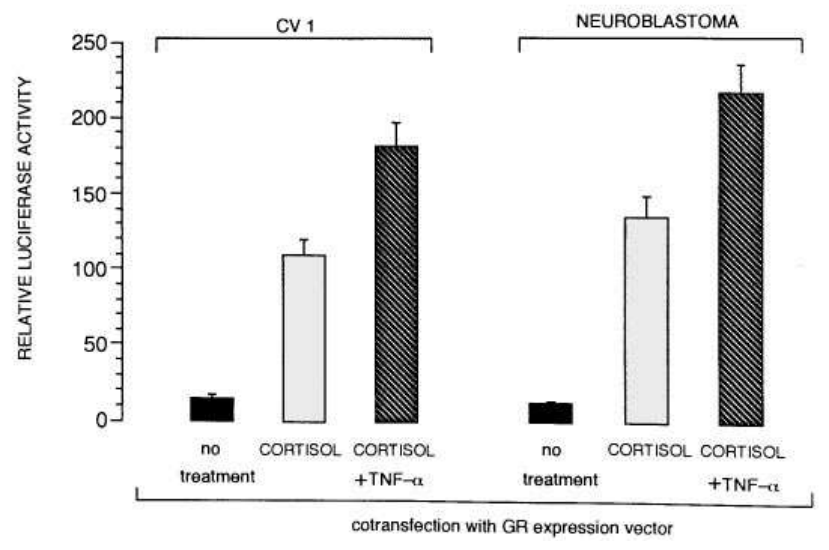

Figure 3. Effect of TNF- $\alpha$ on glucocorticoid-induced transcriptional activity on cells without GRs. (A) Transactivation response of CV1 monkey kidney and SK-N-MC human neuroblastoma (expressing TNF receptor but not GR) transfected cell lines. Cells were transfected with the MTV-LUC construct and stimulated for $24 \mathrm{~h}$ with cortisol ( $3 \mathrm{nM})$, DEX (10 nM), or TNF- $\alpha(0.02 \mathrm{ng} / \mathrm{ml})$. Results of triplicates with a variation from the mean of $<10 \%$ are shown in arbitrary units of LUC activity corrected for transfection efficiency by the corresponding $\beta$-galactosidase activity. Similar results were obtained in two independent experiments for each cell line. (Inset) p55 TNF- $\alpha$ receptor $2.4 \mathrm{~kb}$ mRNA expression in neuroblastoma (lane 2) and CV1(lane 3) cells detected by Northern blot (17 $\mu \mathrm{g}$ of total RNA in each lane). Lane 1 shows phytohemagglutinin-stimulated human peripheral lymphocytes as positive control. (B) TNF- $\alpha$ enhancement of glucocorticoid-induced transcriptional activity of GR via GRE in MTV-LUC and GR expression vector cotransfected CV1 monkey kidney and SK-N-MC human neuroblastoma cells. Cells were cotransfected and stimulated with cortisol $(3 \mathrm{nM})$ and TNF- $\alpha(0.02$ $\mathrm{ng} / \mathrm{ml}$ ) for $24 \mathrm{~h}$. The diagram bar corresponds to the mean \pm SEM of arbitrary units of LUC activity corrected for transfection efficiency by the corresponding $\beta$-galactosidase activity of four independent experiments for each cell line, in which each condition was performed in triplicate. TNF- $\alpha$ itself had no effect on the LUC activity.

Figure 4. Effect of TNF- $\alpha$ on glucocorticoid-induced binding of GR to GREs. $(A)$ EMSA and competition reactions were performed using labeled GRE oligomer and $16 \mu \mathrm{g}$ of nuclear extracts from L-929 cells (lanes 1-6), which were stimulated for $45 \mathrm{~min}$ with $10 \mathrm{nM}$ DEX (lanes 1-4) or DEX plus $0.02 \mathrm{ng} / \mathrm{ml} \mathrm{TNF-} \alpha$ (lanes 5 and 6 ). For competition reactions, an excess of either unlabeled GRE oligonucleotide (lanes 3 and 6 ) or a nonspecific competitor oligomer (lanes 1 and 2)

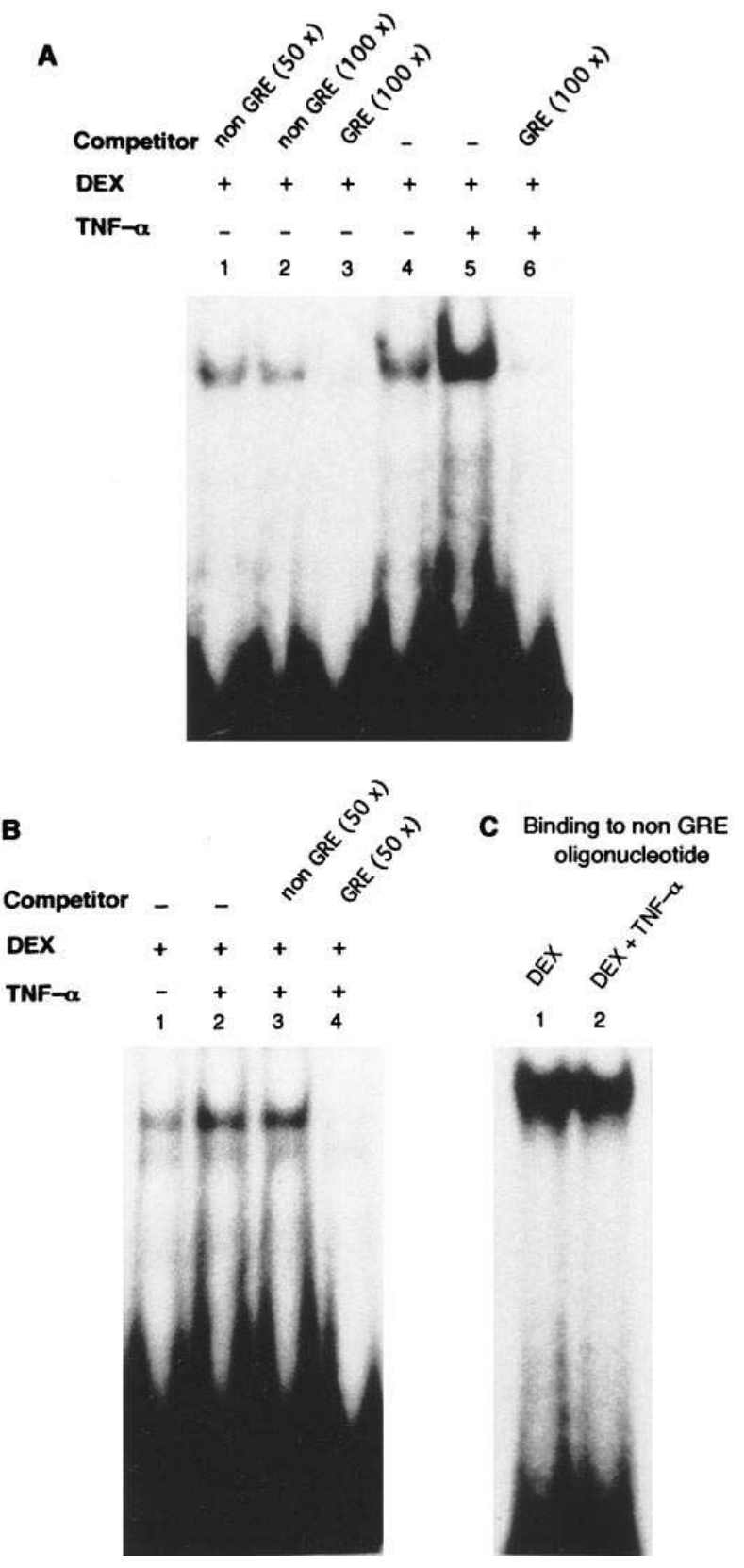

was included in the reaction mixtures. The assay was performed using $1 \mu \mathrm{g}$ of poly $(\mathrm{dI}-\mathrm{dC}) \cdot(\mathrm{dI}-\mathrm{dC})$ in the reaction buffer. Densitometric ratio: DEX plus TNF- $\alpha$ (lane 5)/DEX (lane 4): 1.82 (relative to binding obtained with the same amount of extracts in $C$ ). TNF- $\alpha$ itself had no effect. Similar results were obtained in three independent experiments in which nuclear extracts were obtained after 15,45 , or $60 \mathrm{~min}$ of cell stimulation. $(B)$ EMSA and competition assays were performed using labeled GRE oligomer and $10 \mu \mathrm{g}$ of nuclear proteins from L-929 cells (lanes 1-4), which were stimulated as in $A .600 \mathrm{ng}$ of poly $(\mathrm{dI}-\mathrm{dC}) \cdot(\mathrm{dI}-\mathrm{dC})$ was used in the incubation buffer. Densitometric ratio: DEX plus TNF- $\alpha$ (lane 2)/DEX (lane 1): 1.38 (relative to binding obtained with the same amount of extracts with the oligonucleotide CCAAT). Similar results were obtained in two additional independent experiments. $(C)$ The EMSA was performed using the same amount $(16 \mu \mathrm{g})$ of the same nuclear extracts used in $A$ and labeled oligonucleotide CCAAT (corresponding to other DNA-protein complexes not related to GR/GRE), confirming that they contain the same amount of proteins. The assay was performed using 1 $\mu \mathrm{g}$ of poly $(\mathrm{dI}-\mathrm{dC}) \cdot(\mathrm{dI}-\mathrm{dC})$ in the reaction buffer. Similar results were obtained with all the extracts used in $A$ and $B$. 


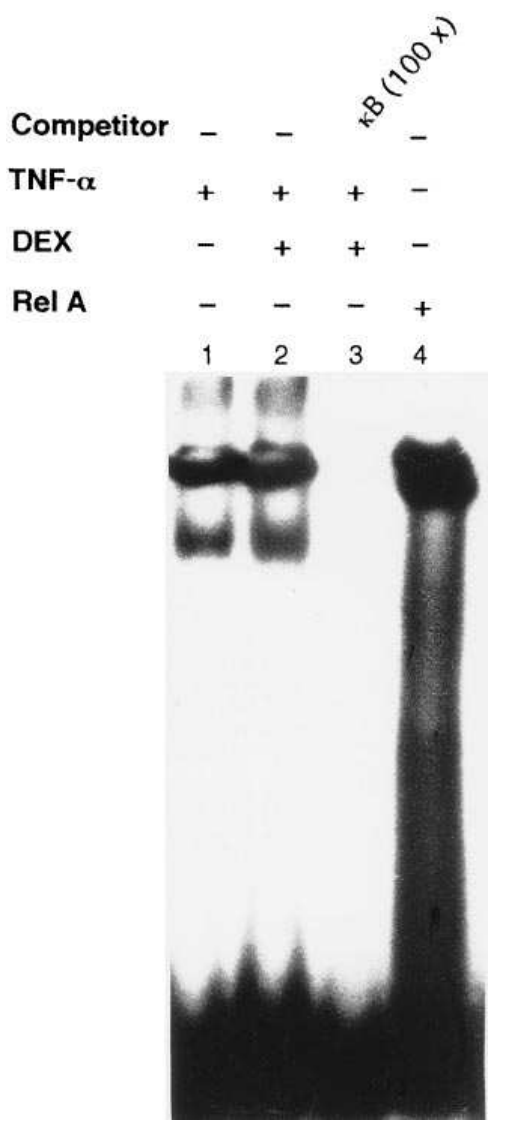

Figure 5. Effect of glucocorticoids on TNF- $\alpha-$ induced $\mathrm{NF}_{\kappa} \mathrm{B}$ binding. EMSA and competition reactions were performed using labeled $\mathrm{NF} \kappa \mathrm{B}$ binding oligomer and $16 \mu \mathrm{g}$ of nuclear extracts from L-929 cells (lanes 1-3), which were stimulated for $45 \mathrm{~min}$ with $0.02 \mathrm{ng} / \mathrm{ml} \mathrm{TNF}-\alpha$ (lane 1 ) or TNF- $\alpha$ plus $10 \mathrm{nM}$ DEX (lanes 2 and 3). For competition reactions, an excess of unlabeled NFKB binding oligomer $(\kappa B)$ (lane 3$)$ was included in the reaction mixture. RelA was used as positive control (lane 4 ). The assay was performed using $1 \mu \mathrm{g}$ of poly $(\mathrm{dI}-\mathrm{dC}) \cdot(\mathrm{dI}-\mathrm{dC})$ in the reaction buffer. Similar results were obtained in three independent experiments in which nuclear extracts were obtained at the indicated time and also at 15, 60, and $120 \mathrm{~min}$. intensities (corresponding to other DNA-protein complexes not related to GR/GRE) were detected between TNF- $\alpha$ plus DEX and DEX treated cells (Fig. $4 C$, lanes 1 and 2). This confirms that equal amounts of protein are compared in Fig. 4, $A$ and $B$, and that the enhancement induced by TNF- $\alpha$ is specific for the GRE oligomer. No shift or extra bands were observed with TNF- $\alpha$ in the mobility of the GR/GRE complex, indicating that the TNF- $\alpha$ treatment does not induce any new protein that interacts directly with this complex (Fig. $4 A$, lane 5 and Fig. $4 \mathrm{~B}$, lane 2). Compatible with the results obtained in the transfection experiments using a vector lacking GREs (Fig. 1, inset), the TNF- $\alpha$-induced enhancement of the GR/GRE binding observed when using a GRE oligomer, indicates that this effect does not necessarily require other DNA sequences.

At these same time points, and even up to 120 min after stimulation, DEX did not alter the NFkB binding induced by TNF- $\alpha$ in L-929 cells (Fig. 5).

$T N F-\alpha$ increases the sensitivity to glucocorticoid action. These changes had marked implications for the biological action of TNF- $\alpha$ and glucocorticoids on L-929 cells. The cytotoxicity/ apoptosis induced by TNF- $\alpha$ in L-929 cells was shown to be inhibited by glucocorticoids (29-31). We used human TNF- $\alpha$ that binds only to the mouse p55 receptor subtype that belongs to the family of receptors, such as FAS/APO1, that mediate apoptosis $(32,33)$, particularly in L-929 fibroblasts (34), and measured both apoptosis and cytotoxicity, with and without TNF- $\alpha$ priming.

As shown previously by flow cytometric analysis (30), DEX reduced the number of apoptotic cells $(\mathrm{TNF}-\alpha 60 \mathrm{ng} / \mathrm{ml}=$ $264 \pm 75$ from total $=450$ cells, TNF- $\alpha 60 \mathrm{ng} / \mathrm{ml}+$ DEX $10 \mathrm{nM}$ $=57 \pm 12$ from total $=300$ cells) established by the TUNEL

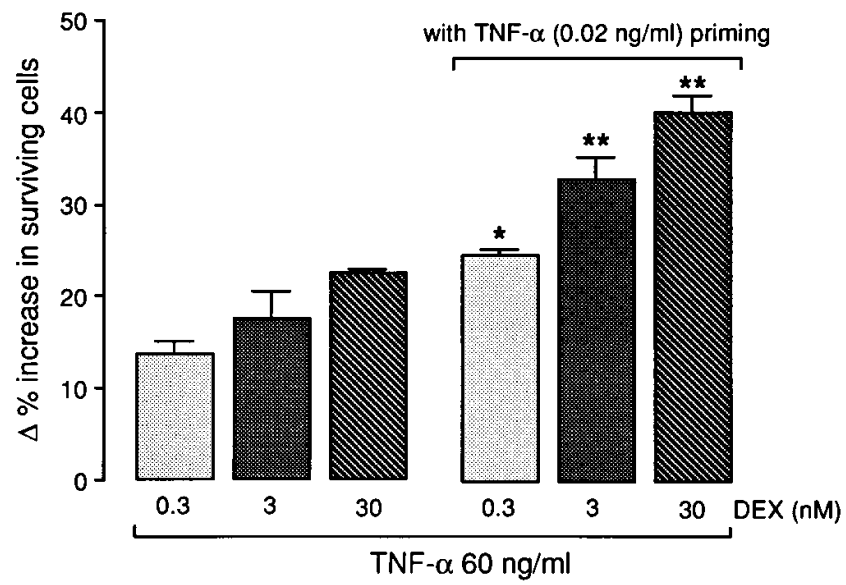

Figure 6. Priming with TNF- $\alpha$ increases the efficacy of glucocorticoids to inhibit TNF- $\alpha$-induced cytotoxicity. $\Delta \%$ increase in surviving cells was obtained by subtracting the percentage of surviving cells after TNF- $\alpha 60 \mathrm{ng} / \mathrm{ml}$ without DEX (without priming: $21.09 \pm 0.44 \%$, with priming: $14.83 \pm 0.74 \%$ ) from the corresponding percentage of surviving cells after DEX treatment. 100\% = cells without TNF- $\alpha(60$ $\mathrm{ng} / \mathrm{ml}$ ) or DEX treatment; absorbance values $=0.659 \pm 0.006$ without priming, $0.646 \pm 0.004$ with priming. Priming with TNF- $\alpha(0.02 \mathrm{ng} / \mathrm{ml})$ was performed for $12 \mathrm{~h}$ (percentage of surviving cells after this treatment $=100 \%$ ), medium was replaced, and cells were stimulated for $24 \mathrm{~h}$. Similar results were obtained in five independent experiments with different cytotoxic doses of TNF- $\alpha(5-80 \mathrm{ng} / \mathrm{ml}) . * P<0.05$, $* * P<0.001$ (ANOVA with Scheffé's test, with respect to the corresponding DEX concentration without priming, mean \pm SEM, $n=4$ for each condition). The statistically significant interaction term of DEX treatment $\times$ TNF- $\alpha$ priming $([\mathrm{F} 1,3]=11.234, P=0.0003)$ indicates the increased efficacy of DEX in the TNF- $\alpha$-primed cells.

method, confirming that glucocorticoids effectively interfere with the cell death program induced by $\mathrm{TNF}_{-} \alpha$. As a functional biological correlate of the enhanced GR number and activity on the GRE-dependent transcriptional activity on L-929 cells, preincubation with a low noncytotoxic dose of $\mathrm{TNF}-\alpha$ increased the sensitivity of TNF- $\alpha$-induced cytotoxicity to DEX inhibition (Fig. 6). Priming with TNF- $\alpha$ thus increases the efficacy of glucocorticoids in blocking TNF- $\alpha$-induced cell death.

Enhancement of glucocorticoid-induced transcriptional activity by cytokines in different cell lines. To establish the generality of this phenomenon, a number of other cell lines derived from different tissues which also express GR and cytokine receptors were transfected with the MTV-CAT construct. In U-373 human glioblastoma cells treated with TNF- $\alpha$ or IL-1 $\beta$ plus DEX (Fig. 7 $A)$, HeLa human epithelioid carcinoma cells after TNF- $\alpha$ plus DEX incubation (Fig. 7 B) and AtT-20 mouse anterior pituitary cells after IL-1 $\beta$ and DEX stimulation (Fig. $7 C$ ), combined DEX and cytokine stimulation, led to an increase in CAT activity compared with DEX action without cytokine treatment. These results show that the phenomenon is not limited to a single type of target cell or cytokine, and may thus reflect a general molecular mechanism whereby cytokines modulate the transcriptional activity of GRs.

\section{Discussion}

The interaction between nuclear receptors and the transcriptional activator AP-1 represents a major form of cross talk between two central signal transduction pathways, one used by ste- 


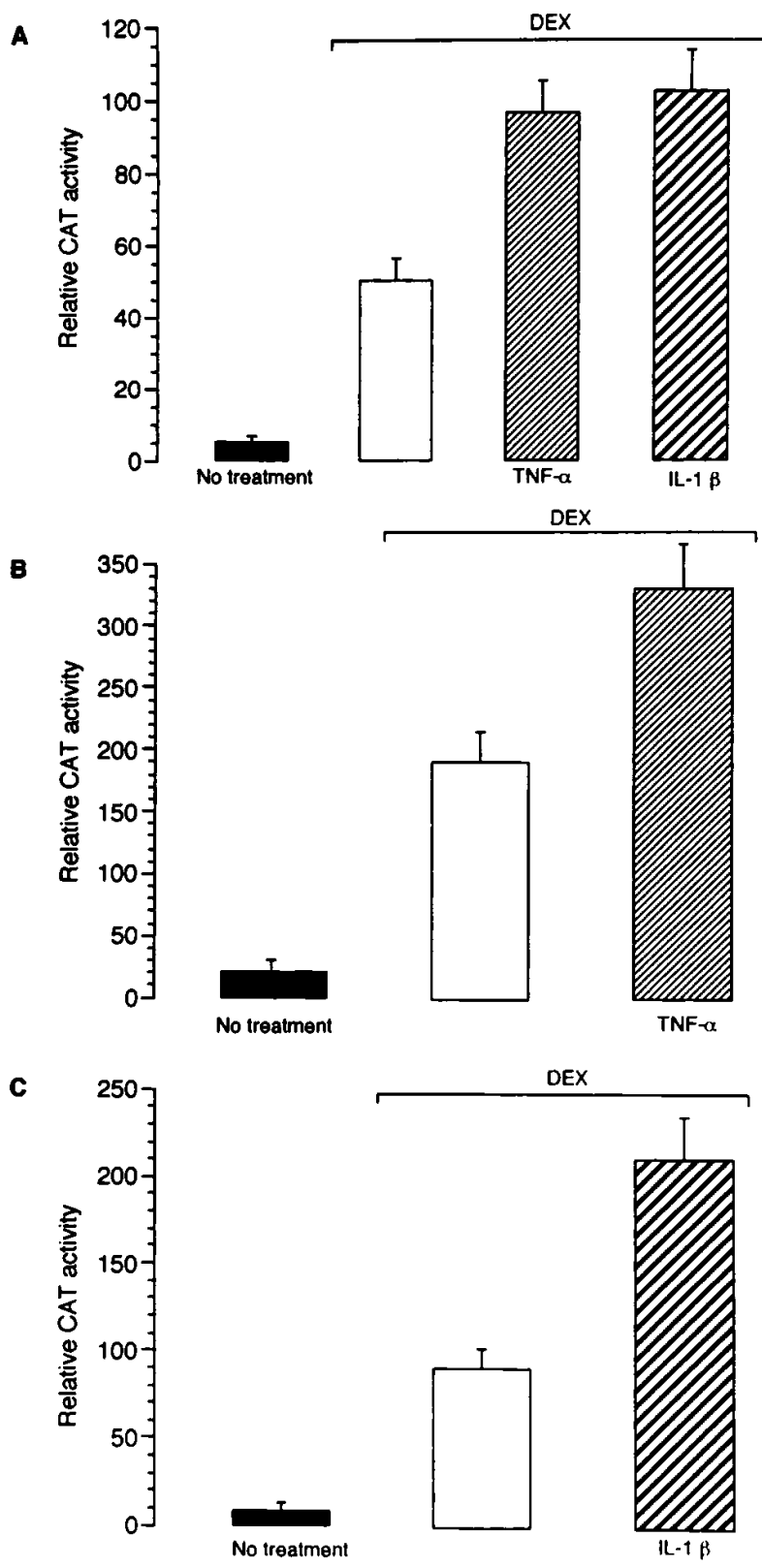

Figure 7. IL- $1 \beta$ and TNF- $\alpha$ enhancement of glucocorticoid-induced transcriptional activity of GR via GRE in different MTV-CAT-transfected cells. IL- $1 \beta$ and TNF- $\alpha$ potentiate DEX-induced transcriptional activity of the GR via the GRE in U-373 glioblastoma $(A)$, HeLa $(B)$, and AtT-20 $(C)$ transfected cells. Cells were transfected with a plasmid MTV-CAT (19) and stimulated for $24 \mathrm{~h}$ with DEX (10 $\mathrm{nM})$, DEX plus IL-1 $100 \mathrm{IU} / \mathrm{ml}$, or DEX plus TNF $0.02 \mathrm{ng} / \mathrm{ml}$. The diagram bars correspond to the mean \pm SEM of the densitometric analysis of CAT assay, standardized by the corresponding $\beta$-galactosidase, of three independent experiments for each cell line, in which each condition was performed in duplicate. TNF- $\alpha$ or IL-1 $\beta$ alone had no effect on CAT activity.

roid and thyroid hormones, as well as by retinoids, and the other by growth factors and cytokines (35-39). This interaction leads to transcriptional interference and inhibition of the expression of AP-1 regulated genes, such as cytokines (35-39). There is also a complex cross talk between $\mathrm{NF} \mathrm{B}$ and GR, discussed below (40-44).
The enhancement of GR transactivation via GRE requires the presence of GR, glucocorticoid hormone, and cytokine in order to occur. This phenomenon can be accounted for in part by an increase in GR number, as shown in Fig. 2. However, it also takes place when cells that do not express GRs are cotransfected with an expression vector for the GR, indicating that other mechanisms, such as increased GR binding to GRE and/or direct interaction of other transcription factors, must also exist. As shown in the EMSA studies, TNF- $\alpha$ increases the DEX-induced binding of the GR to the GRE and does not induce additional transcription factors that interact directly with the GR/GRE complexes. The TNF- $\alpha$ facilitation of the interaction of GR with its binding sites may involve an increase in the nuclear translocation of the GR and/or enhanced accessibility of the GR (i.e., changes in phosphorylation or conformation). We demonstrate, for the first time, that the regulatory loop whereby cytokine transduction signals cross talk with the GR may result in an enhancement of the transcriptional activity of these nuclear hormone receptors. In genes containing DNA sequences which are targets for different transcription factors, further interactions with the GR/ GRE may also occur. Cross-coupling of distinct pathways in certain situations may repress gene transcription but in others may activate gene expression.

There is a complex functional interaction between the GR and NFkB. Two different mechanisms have been postulated: (a) a direct physical association of GR and RelA, the 65-kD NFKB binding protein (40-42); and (b) the inhibition of NFKB without physical association, through the induction by glucocorticoids of the synthesis of the inhibitor IкB $(43,44)$. With regards to $\mathrm{NF} \kappa \mathrm{B}$ activity induced specifically by $\mathrm{TNF}-\alpha$, it has been demonstrated that: (a) DEX inhibits this activation in EMSA studies with nuclear extracts obtained in cells pretreated for 5,12 , or $20 \mathrm{~h}$ with DEX $(41,43)$; and $(b) \mathrm{NF \kappa B}$ released from IкB after TNF- $\alpha$ induction quickly reassociates with newly synthesized $\mathrm{I}_{\kappa} \mathrm{B}$ in the presence of DEX, thus markedly reducing the amount of $\mathrm{NFKB}$ that translocates to the nucleus $(43,44)$. In our experiments, as a net result of all the mechanisms involved (the balance of the putative formation of $\mathrm{NF \kappa B} / \mathrm{GR}$ complexes and the increase in the synthesis of I $\mathrm{B}$ sequestrating NFKB, and the enhancement of GR binding of GRE), DEX does not change the NFkB activity induced by $\mathrm{TNF}-\alpha$, at the same time points at which $\mathrm{TNF}-\alpha$ enhances the binding of GR to GRE. Although the NF-kB/GR complexes may downtitrate the activation of GRE induced by TNF- $\alpha$ (as shown in other cells in which cotransfection with an expression vector for RelA inhibits GRE reporter plasmids [40-42]), our EMSA and transfection experiments show that the net result of TNF- $\alpha$ stimulation with regards to GRE is an enhancement of the GR transactivation via GRE. Furthermore, the enhancement of GR number by TNF- $\alpha$ will contribute to the dampening of TNF- $\alpha$ biological action by two independent but concomitant pathways, the inhibition of NFKB activation (by the formation of $\mathrm{NF \kappa} B / G R$ complexes and/or the augmentation of IкB) (40-44) and the enhancement of GRE responsive genes.

TNF- $\alpha$ is a pleiotropic cytokine, capable of killing mammalian cells in vitro and in vivo through a number of cellular effects, including cytotoxicity/apoptosis (32-34, 45-47). The shock and tissue injury that occur in response to bacterial endotoxin is largely mediated by IL- 1 and TNF- $\alpha$, which can also mediate cellular injury on normal tissues $(6,47-51)$. The re- 
duction of side effects of these cytokines is a major goal in the successful clinical management of endotoxemia. This may be achieved by desensitizing the target cells to their lethal effects. A state of hyporesponsiveness to endotoxin reactions (known as endotoxin tolerance) is induced in animals by prior administration of small amounts of endotoxin (52-54). Glucocorticoids are directly involved in endotoxin tolerance, since adrenalectomized animals do not become endotoxin tolerant and tolerance can be restored by DEX administration (54). Adrenalectomy is known to increase sensitivity to the lethal effects of TNF- $\alpha$ in mice (54-56), and the same dose of antiTNF- $\alpha$ that blocks its lethality in normal mice is ineffective in adrenalectomized animals (54). Adrenalectomized animals that receive oral DEX $20 \mathrm{~h}$ before endotoxin injection produce significant amounts of TNF- $\alpha$ but become tolerant (i.e., show a survival rate similar to that of normal mice) (54). The underlying mechanism remains unknown. However, based on our results, it is likely that the observed increase in tolerance is due to the increased sensitivity, induced by $\mathrm{TNF}_{-} \alpha$, of the target cells to the remaining low glucocorticoid concentration. Thus, cytokine enhancement of the negative control of their own biological action provides a new tool with which to lower cytokine lethal effects on target cells. Treatments that can increase the apoptotic thresholds of specific cells may be beneficial in the treatment of disorders associated with cell loss. After cytokine priming, GR-responsive genes present in target cells for cytokines will become more sensitive to regulation by glucocorticoids, as does the program of gene expression involved in the cell death induced by TNF- $\alpha$.

As mentioned above, cytokine-induced glucocorticoid secretion acts as an important safeguard in preventing cytokine deleterious effects, since glucocorticoids in turn inhibit cytokine synthesis (1-7). We now provide evidence for a cellular and molecular level of regulation between cytokines and glucocorticoids at the level of their target cells, the end result of which is to inhibit the biological action of cytokines. One of the physiologically critical functions of glucocorticoids is to prevent the immune system from overreacting (57). By both inducing glucocorticoid production and enhancing their inhibitory action on target cells, cytokines contribute to the control of this overshooting.

\section{Acknowledgments}

We thank Dr. Ronald M. Evans for the plasmids MTV-CAT, MTVLUC, $\Delta$ MTV-CAT, and pRShGR $\alpha$, Dr. Katty Barrett for the p55 TNF- $\alpha$ R cDNA, and Drs. G. Wick, H. Besedovsky, S. McCann, A. Kornblihtt, and P. Rosenfeld for comments on the manuscript.

This study was supported by grants CI $1 *$-CT $93-0092$ from the Commission of the European Communities and I/68 430 and I/70 543 from the Volkswagen-Stiftung, Germany.

\section{References}

1. Besedovsky, H., A. Del Rey, E. Sorkin, and C.A. Dinarello. 1986. Immunoregulatory feedback between interleukin-1 and glucocorticoid hormones. Science (Wash. DC). 233:652-654.

2. Sapolsky, R., C. Rivier, G. Yamamoto, P. Plotsky, and W. Vale. 1987. Interleukin-1 stimulates the secretion of hypothalamic corticotropin-releasing factor. Science (Wash. DC). 238:22-24.

3. Snyder, D.S., and E.R. Unanue. 1982. Corticosteroids inhibit murine macrophage Ia expression and interleukin 1 production. J. Immunol. 129:18031805 .

4. Gillis, S., G.R. Crabtree, and K. Smith. 1979. Glucocorticoid-induced inhibition of T-cell growth factor production. I. The effect of mitogen-induced lymphocyte proliferation. J. Immunol. 123:1624-1631.

5. Cupps, T.R., and A.S. Fauci. 1982. Corticosteroid-mediated immunoregulation in man. Immunol. Rev. 65:133-155.

6. Beutler, B., N. Krochin, I.W. Milsark, C. Luedke, and A. Cerami. 1986. Control of cachectin (tumor necrosis factor) synthesis: mechanisms of endotoxin resistance. Science (Wash. DC). 232:977-980.

7. Arzt, E., J. Sauer, T. Pollmächer, M. Labeur, F. Holsboer, J. Reul, and G.K. Stalla. 1994. Glucocorticoids suppress interleukin-1 receptor antagonist synthesis following induction by endotoxin. Endocrinology. 134:672-677.

8. Salkowski, C.A., and S.N. Vogel. 1992. Lipopolysaccharide increases glucocorticoid receptor expression in murine macrophages. J. Immunol. 149:40414047.

9. Rakasz, E., A. Gal, J. Biró, G. Balas, and A. Falus. 1993. Modulation of glucocorticosteroid binding in human lymphoid, monocytoid and hepatoma cell lines by inflammatory cytokines interleukin (IL)-1 $\beta$, IL-6 and tumor necrosis factor (TNF)- $\alpha$. Scand. J. Immunol. 37:684-689.

10. Ballard, P.L., J.D. Baxter, S.J. Higgins, G.G. Rousseau, and G.M. Tomkins. 1974. General presence of glucocorticoid receptors in mammalian tissues. Endocrinology. 94:998-1002.

11. Vamvakopoulos, N.C., and G.P. Chrousos. 1994. Hormonal regulation of human corticotropin-releasing hormone gene expression: implications for the stress response and immune/inflammatory reaction. Endocr. Rev. 15:409420 .

12. Tai, P.-K.K., M.W. Albers, H. Chang, L.E. Faber, and S.L. Schreiber. 1992. Association of a 59-kilodalton immunophilin with the glucocorticoid receptor complex. Science (Wash. DC). 256:1315-1318.

13. Ning, Y.-M., and E.R. Sánchez. 1993. Potentiation of glucocorticoid receptor-mediated gene expression by the immunophilin ligands FK506 and rapamycin. J. Biol. Chem. 268:6073-6076.

14. Hollenberg, S.M., and R.M. Evans. 1988. Multiple and cooperative trans-activation domains of the human glucocorticoid receptor. Cell. 55:899906.

15. Kühnel, B., E. Buetti, and H. Diggelmann. 1986. Functional analysis of the glucocorticoid regulatory elements present in the mouse mammary tumor virus long terminal repeat. J. Mol. Biol. 190:367-378.

16. Hollenberg, S.M., C. Weinberger, E.S. Ong, G. Cerelli, A. Oro, R. Lebo, E.B. Thomson, M.G. Rosenfeld, and R.M. Evans. 1985. Primary structure and expression of a functional glucocorticoid receptor cDNA. Nature (Lond.). 318:635-641.

17. Wigler, M., R. Sweet, G.K. Sim, B. Wold, A. Pellicer, E. Lazy, T. Maniatis, S. Silverstein, and R. Axel. 1979. Transformation of mammalian cells with genes from procaryotes and eucaryotes. Cell. 16:777-785.

18. Gorman, C.M., L.F. Moffat, and B.H. Howard. 1982. Recombinant genomes which express chloramphenicol acetyltransferase in mammalian cells. Mol. Cell. Biol. 2:1044-1051.

19. Trapp, T., R. Rupprecht, M. Castrén, J.M.H.M. Reul, and F. Holsboer. 1994. Heterodimerization between mineralocorticoid and glucocorticoid receptor: a new principle of glucocorticoid action in the CNS. Neuron. 13:1457-1462.

20. Rupprecht, R., J.L. Arriza, D. Spengler, J.M.H.M. Reul, R.M. Evans, F. Holsboer, and K. Damm. 1993. Transactivation and synergistic properties of the mineralocorticoid receptor: relationship to the glucocorticoid receptor. Mol. Endocrinol. 7:597-603.

21. Arriza, J.L., R.B. Simerly, L.W. Swanson, and R.M. Evans. 1988. The neuronal mineralocorticoid receptor as a mediator of glucocorticoid response. Neuron. 1:887-900.

22. Herbomel, P., B. Bourachot, and M. Yaniv. 1984. Two distinct enhancers with different cell specificities coexist in the regulatory region of polioma. Cell. 39:653-662.

23. Arzt, E., G. Stelzer, U. Renner, M. Lange, O.A. Müller, and G.K. Stalla. 1992. Interleukin-2 and interleukin-2 receptor expression in human corticotrophic adenoma and murine pituitary cell cultures. J. Clin. Invest. 90:19441951.

24. Costas, M., D. Mella, M. Criscuolo, A. Díaz, S. Finkielman, V.E. Nahmod, and E. Arzt. 1993. Superinduction of mitogen-stimulated interferon- $\gamma$ production and other lymphokines by Sendai virus. J. Interferon Res. 13:407412.

25. Sgonc, R., G. Boeck, H. Dietrich, J. Gruber, H. Recbeis, and G. Wick. 1994. Simultaneous determination of cell surface antigens and apoptosis. TIG (Trends Genet). 10:41-42.

26. Reul, J.M.H.M., I. Stec, G.J. Wiegers, M.S. Labeur, A.C.E. Linthorst, E. Arzt, and F. Holsboer. 1994. Prenatal immune challenge alters the hypothalamic-pituitary-adrenocortical axis in adult rats. J. Clin. Invest. 93:2600-2607.

27. Lowry, O.H., N.J. Rosebrough, A.L. Farr, and R.J. Randall. 1951. Protein measurement with the Folin phenol reagent. J. Biol. Chem. 193:265-275.

28. Cidlowski, J.A., and N.B. Cidlowski. 1982. Glucocorticoid receptors and the cell cycle: evidence that the accumulation of glucocorticoid receptors during the $\mathrm{S}$ phase of the cycle is dependent on ribonucleic acid and protein synthesis. Endocrinology. 110:1653-1662.

29. Kull, F.C., Jr. 1988. Reduction in tumor necrosis factor receptor affinity and cytotoxicity by glucocorticoids. Biochem. Biophys. Res. Commun. 153:402409.

30. Pagliacci, M.C., G. Migliorati, M. Smacchia, F. Grignani, C. Riccardi, 
and I. Nicoletti. 1993. Cellular stress and glucocorticoid hormones protect L-929 mouse fibroblasts from tumor necrosis factor alpha cytotoxicity. J. Endocrinol. Invest. 16:591-599.

31. Reid, T., P. Louie, and R.A. Heller. 1995. Mechanisms of tumor necrosis factor cytotoxicity and the cytotoxic signals transduced by the p75-tumor necrosis factor receptor. Circ. Shock. 44:84-90.

32. Boldin, M.P., I.L. Mett, E.E. Varfolomeev, I. Chumakov, Y. ShemerAvni, J.H. Camonis, and D. Wallach. 1995. Self-association of the "death domains" of the p55 tumor necrosis factor (TNF) receptor and Fas/APO1 prompts signaling for TNF and Fas/APO1 effects. J. Biol. Chem. 270:387-391.

33. Nagata, S., and P. Golstein. 1995. The Fas death factor. Science (Wash. DC). $267: 1449-1455$

34. Tartaglia, L.A., T.M. Ayres, G.H.W. Wong, and D.V. Goeddel. 1993. A novel domain within the $55 \mathrm{kD}$ TNF receptor signals cell death. Cell. 74:845853.

35. Vacca, A., M.P. Felli, A.R. Farina, S. Martinotti, M. Maroder, I. Screpanti, D. Meco, E. Petrangeli, L. Frati, and A. Gulino. 1992. Glucocorticoid receptor-mediated suppression of the interleukin 2 gene expression through impairment of the cooperativity between nuclear factor of activated $\mathrm{T}$ cells and AP-1 enhancer elements. J. Exp. Med. 175:637-646.

36. Lucibello, F.C., E.P. Slater, K.U. Jooss, M. Beato, and R. Müller. 1990. Mutual transrepression of Fos and the glucocorticoid receptor: involvement of a functional domain in Fos which is absent in FosB. EMBO (Eur. Mol. Biol. Organ.) J. 9:2827-2834

37. Diamond, M.I., J.N. Miner, S.K. Yoshinaga, and K.R. Yamamoto. 1990. Transcription factor interactions: selectors of positive or negative regulation from a single DNA element. Science (Wash. DC). 249:1266-1272.

38. Jonat, G., H.J. Rahmsdorf, K.-K. Park, A.C.B. Cato, S. Gebel, H. Ponta, and P. Herrlich. 1990. Antitumor promotion and antiinflammation: down-modulation of AP-1 (Fos/Jun) activity by glucocorticoid hormone. Cell. 62:11891204.

39. Yang-Yen, H.F., J.C. Chambard, Y.L. Sun, T. Smeal, T.J. Schimdt, J. Drouin, and M. Karin. 1990. Transcriptional interference between c-Jun and the glucocorticoid receptor: mutual inhibition of DNA binding due to direct protein-protein interaction. Cell. 62:1205-1215.

40. Ray, A., and K.E. Prefontaine. 1994. Physical association and functional antagonism between the p65 subunit of transcription factor NF-кB and the glucocorticoid receptor. Proc. Natl. Acad. Sci. USA. 91:752-756.

41. Scheinman, R.I., A. Gualberto, C.M. Jewell, J.A. Cidlowski, and A.S. Baldwin, Jr. 1995. Characterization of mechanisms involved in transrepression of NF-кB by activated glucocorticoid receptors. Mol. Cell. Biol. 15:943-953.

42. Caldenhoven, E., J. Liden, S. Wissink, A. Van de Stolpe, J. Raaijmakers, L. Koenderman, S. Okret, J.-A. Gustafsson, and P.T. Van der Saag. 1995. Negative cross-talk between RelA and the glucocorticoid receptor: a possible mechanism for the antiinflammatory action of glucocorticoids. Mol. Endocrinol. 9:401-412.

43. Scheinman, R.I., P.C. Cogswell, A.K. Lofquist, and A.S. Baldwin, Jr. 1995. Role of transcriptional activation of IKB in mediation of immunosuppres- sion by glucocorticoids. Science (Wash. DC). 270:283-286.

44. Auphan, N., J.A. DiDonato, C. Rosette, A. Helmberg, and M. Karin 1995. Immunosuppression by glucocorticoids: inhibition of $\mathrm{NF} \times \mathrm{B}$ activity through induction of IкB synthesis. Science (Wash. DC). 270:286-290.

45. Barbara, J.A.J., W.B. Smith, J.R. Gamble, X. Van Ostade, P. Vandenabeele, J. Tavernier, W. Fiers, M.A. Vadas, and A.F. Lopez. 1994. Dissociation of TNF- $\alpha$ cytotoxic and proinflammatory activities by $\mathrm{p} 55$ receptor and $\mathrm{p} 75$ receptor-selective TNF- $\alpha$ mutants. EMBO (Eur. Mol. Biol. Organ.) J. 13:843850

46. Clement, M.-V., and I. Stamenkovic. 1994. Fas and tumor necrosis factor receptor-mediated cell death: similarities and distinctions. J. Exp. Med. 180 557-567.

47. Beutler, B., and A. Cerami. 1986. Cachectin and tumour necrosis factor as two sides of the same biological coin. Nature (Lond.). 320:584-588.

48. Beutler, B., I.W. Milsark, and A.C. Cerami. 1985. Passive immunization against cachectin/tumor necrosis factor protects mice from lethal effect of endotoxin. Science (Wash. DC). 229:869-871.

49. Tracey, K.J., B. Beutler, S.F. Lowry, J. Merryweather, S. Wolpe, I.W. Milsark, R.J. Hariri, T.J. Fahey III, A. Zentella, J.D. Albert, et al. 1986. Shock and tissue injury induced by recombinant human cachectin. Science (Wash. DC). 234:470-474.

50. Van Zee, K.J., S.A. Stackpole, W.J. Montegut, M.A. Rogy, S.E. Calvano, K.C. Hsu, M. Chao, C.L. Meschter, H. Loetscher, D. Stüber, et al. 1994 A human tumor necrosis factor (TNF) $\alpha$ mutant that binds exclusively to the p55 TNF receptor produces toxicity in the baboon. J. Exp. Med. 179:1185-1191.

51. Okusawa, S., J.A. Gelfand, T. Ikejima, R.J. Connolly, and C.A. Dinarello. 1988. Interleukin 1 induces a shock-like state in rabbits. Synergism with tumor necrosis factor and the effect of cyclooxygenase inhibition. J. Clin. Invest. 81:1162-1172.

52. Matsuura, M., M. Kiso, A. Hasegawa, and M. Nakano. 1994. Multistep regulation mechanisms for tolerance induction to lipopolysaccharide lethality in the tumor necrosis factor- $\alpha$ mediated pathway. Eur. J. Biochem. 221:335-341.

53. Szabó, C., C. Thiemermann, C.-C. Wu, M. Perretti, and J.R. Vane. 1994 Attenuation of the induction of nitric oxide synthase by endogenous glucocorticoids accounts for endotoxin tolerance in vivo. Proc. Natl. Acad. Sci. USA. 91: 271-275.

54. Evans, G.E., and S.H. Zuckerman. 1991. Glucocorticoid-dependent and -independent mechanisms involved in lipopolysaccharide tolerance. Eur. J. Immunol. 21:1973-1979.

55. Hinshaw, L.B., B.K. Beller-Todd, and L.T. Archer. 1982. Current management of the septic shock patient: experimental bases for treatment. Circ. Shock. 9:545-553.

56. Parant, M., C. Le Contel, F. Parant, and L. Chedid. 1991. Influence of endogenous glucocorticoid on endotoxin-induced production of circulating TNF- $\alpha$. Lymphokine Cytokine Res. 10:265-271.

57. Munck, A., P.M. Guyre, and N.J. Holbrook. 1984. Physiological functions of glucocorticoids in stress and their relation to pharmacological actions. Endocrinol. Rev. 5:25-44. 